\title{
Climate Change and Agriculture: An Indian Perspective: A Review
}

\author{
Monika Shukla, B.L. Jangid ${ }^{1}$, Vikas Khandelwal' ${ }^{2}$ A. Keerthika ${ }^{3}$, A.K. Shukla ${ }^{3}$
}

10.18805/ag.R-2190

\begin{abstract}
Industrial revolution and fast deforestation in $20^{\text {th }}$ century pushes the earth to face climate change. Climate change became one of the most important global environmental challenges of the $21^{\text {st }}$ century. Besides other weather abnormalities it is potential threat to world food security as agriculture production is directly dependent on various weather parameters. Even a small alteration in climate, adversely affects agriculture by decreasing the production. Global temperatures have already increased by $0.70^{\circ} \mathrm{C}$ over the past century and prediction of more rise of temperature is there. Possible changes in temperature, precipitation and $\mathrm{CO}_{2} \mathrm{Concentration}$ are expected to significantly impact crop growth. India could experience a $40 \%$ decline in agricultural productivity by the 2080 s. Various food grain crops are going to affect badly under the temperature rise situation. It has been projected that under the scenario of a $2.50^{\circ} \mathrm{C}$ to $4.90^{\circ} \mathrm{C}$ temperature rise, rice yields will drop by $32 \%$ to $40 \%$ and wheat yields by $41 \%$ to $52 \%$. This paper summarized study related to climate change projections and its impact on production of various crops.
\end{abstract}

Key words: Agriculture, Climate change, Global warming, Mitigation.

Climate change is any change in climate over time that is attributed directly or indirectly to human activity that alters the composition of the global atmosphere in addition to natural climate variability observed over comparable time periods (IPCC, 2007). During the $20^{\text {th }}$ century increase in global average temperatures and change in rainfall rates around the world was observed (IPCC, 2001). In 1972, global warming officially declared as an international issue and the World Meteorological Organization (WMO) and United Nations Environment Programme (UNEP) also declared that carbon dioxide is the principal cause of climate change because of its highest contribution in global warming. The world has been facing various environmental issues for the last 2-3 decades and economic losses from natural disasters are rising globally. By 2100 Prediction for average temperature change is 2.33 to $4.78^{\circ} \mathrm{C}$ with a doubling of $\mathrm{CO}_{2}$ concentrations and the mean global sea levels rise from $18 \mathrm{~cm}$ to $140 \mathrm{~cm}$ (IPCC, 2007).

Agriculture is the backbone of the Indian economy and provides food and livelihood to major population. Agriculture sector is highly vulnerable to weather abnormalities. In agriculture, selection of crop is specific to suitable climate, soil type and resource availability, hence, agricultural production is largely reliant on climatic conditions (Srinivasarao et al., 2016a; Bal and Minhas, 2017). Agricultural production is sensitive in two categories of climate induced effects (a) Direct effects, from changes in weather parameters as well as extreme weather events and (b) Indirect effects, due to changes in soil moisture and change in pests and diseases occurrence. These effects on agricultural system will have negative impact on agricultural production. According to global report prediction, loss of $10-40 \%$ in crop productivity will be observed in the year 2100 (Anonymous, 2019).
ICAR-Central Soil Salinity Research Institute, Regional Research Station, Bharuch-392 012, Gujarat, India.

'ICAR-Agricultural Technology Application Research Institute, (CAZRI Campus), Jodhpur-342 005, Rajasthan, India.

${ }^{2}$ ICAR-AICRP on Pearl millet, Agricultural Research Stations, Agriculture University, Jodhpur-342 304, Rajasthan, India.

3ICAR-Central Arid Zone Research Institute, Regional Research Station - Pali Marwar-306 401, Rajasthan, India.

Corresponding Author: Monika Shukla, ICAR-Central Soil Salinity Research Institute, Regional Research Station, Bharuch-392 012, Gujarat, India. Email: agri.monika@gmail.com

How to cite this article: Shukla, M., Jangid, B.L., Khandelwal, V. Keerthika, A. and Shukla, A.K. (2021). Climate Change and Agriculture: An Indian Perspective: A Review Agricultural Reviews. DOI: 10.18805/ag.R-2190.

Submitted: 12-03-2021 Accepted: 15-06-2021 Online:06-09-2021

\section{Indian scenario of climate change Current scenario}

Analysis done by the Indian Meteorology Department and the Indian Institute of Tropical Meteorology, Pune, shows that temperature, heat waves, droughts, floods and sea level are increasing in India. Analysis of data for the period 1901 to 2009 suggests that annual mean temperature for the country as a whole has risen by $0.56^{\circ} \mathrm{C}$ over this period (Attri and Tyagi, 2010; Kothawale et al., 2010) and the value showed an increasing trend of $0.61^{\circ} \mathrm{C}$ per 100 years for the period 1901 to 2019 with significant increasing trend in maximum temperature $\left(1^{\circ} \mathrm{C}\right.$ per 100 years) and relatively lower increasing trend $\left(0.22^{\circ} \mathrm{C}\right.$ per 100 years $)$ in minimum temperature. The seven warmest years on record since country's records started in 1901 were $2016\left(+0.71^{\circ} \mathrm{C}\right), 2009$ 
$\left(+0.541^{\circ} \mathrm{C}\right), 2017\left(+0.539^{\circ} \mathrm{C}\right), 2010\left(+0.54^{\circ} \mathrm{C}\right)$ and 2015 $\left(+0.42^{\circ} \mathrm{C}\right)$ and $2018\left(+0.41^{\circ} \mathrm{C}\right)$ and 2019 . The notable thing is that 11 out of 15 warmest years were during the recent past fifteen years from 2005 to 2019 (IMD, 2020). This warming was mainly contributed by the winter and postmonsoon seasons, which have been increased by $0.80^{\circ} \mathrm{C}$ and $0.82^{\circ} \mathrm{C}$ in the last hundred years respectively. Mean temperature increased by about $0.20^{\circ} \mathrm{C}$ per decade for the period 1971 to 2007, with a much steeper increase in minimum temperature. Season wise, maximum rise in temperature was observed during the post-monsoon season $\left(0.77^{\circ} \mathrm{C}\right)$ followed by winter season $\left(0.70^{\circ} \mathrm{C}\right)$, pre-monsoon season $\left(0.64^{\circ} \mathrm{C}\right)$ and monsoon season $\left(0.33^{\circ} \mathrm{C}\right)(\mathrm{IMD}, 2009$; Attri and Tyagi, 2010).

All India annual and monsoon rainfall for the period 1901 to 2009 do not show any significant trend (Attri and Tyagi, 2010). However, some regional patterns were noted as areas along the West coast, North Andhra Pradesh and Northwest India reported an increase in monsoon rainfall. Some places across east Madhya Pradesh and adjoining areas, North-east India and parts of Gujarat and Kerala recorded a decreasing trend $(-6.00$ to $-8.00 \%$ of normal over 100 years) (Stephenson et al., 2001; Singh and Sontakke, 2002; $\mathrm{Pal}, 2009$ ). During year 2019, annual mean temperature, of India, was $0.36^{\circ} \mathrm{C}$ above average of $1981-2010$. The country averaged seasonal mean temperatures were also above the average during all the four seasons with the monsoon season (Jun-Sep, with difference of $+0.58^{\circ} \mathrm{C}$ ) being the warmest since 1901. Intensity of storm was also higher during 2019 and 8 cyclonic storms were formed over the Indian seas (IMD 2020).

\section{Future Projections}

Study on projection of future change of different weather parameters has been started a long ago by using different models and long term data based calculations. As predicted, the south Asian zones may experience a warming effect of $2^{\circ} \mathrm{C}$ to $6^{\circ} \mathrm{C}$ during the $21^{\text {st }}$ century (Ravindranath, 2007) and Indian sub-continent and other continents are highly at risk to all kinds of existing climate change. Surface warming will be more pronounced during winter than during monsoon season in future. By 2080's during winter, the mean surface temperature increase over India would be at least $4^{\circ} \mathrm{C}$, while during monsoon, it may range between $2.9^{\circ} \mathrm{C}$ and $4.60^{\circ} \mathrm{C}$ (Table 1). An increase of about 7 to $10 \%$ in annual mean precipitation is predicted over the Indian subcontinent by 2080 's however a decline of 5 to $25 \%$ in mean winter precipitation is likely to happen (Lal et al., 2001). As predicted the western semi-arid zones of India will receive higher rainfall than normal, while the central parts of India will experience rainfall reduction of 10 to $20 \%$ during winter by 2050 's.

Number of rainy days will be decrease over a major part of the country. This decrease predicted to be greater in the western and central parts (by more than 15 days), while near the Himalayan foothills (Uttaranchal) and in the Northeast the number of rainy days may increase by $5-10$ days (NATCOM, 2004). Cline (2007) studied projected changes in climate in India for 2070 to 2099 with reference to the base period 1960 to 1990 and he reported that all four regions of India the temperature is going to increase from more than 2 to $5^{\circ} \mathrm{C}$. North east and north west temperature predicted to be higher than the other regions. The Southeastern regions of India will show more than $32 \%$ decline in precipitation from January to March and in the northwestern regions of India, the precipitation is projected to increase in 2070 to 2099 (increase of $57 \%$ of average) in the months of October-December (Table 2).

\section{Impact of climate change on agriculture Current scenario}

Among all the sectors of economic activities, agricultural sector is heavily dependent on weather and climate and reveals high sensitivity and resilience to climate change. The inter-annual monsoon rainfall variability in India leads to large-scale droughts and floods, resulting in a major effect on agricultural production (Kumar et al., 2004) and on the economy of the country. The increase in minimum temperatures increases maintenance respiration requirement of the crops and thus further reduces net growth and productivity (Aggarwal, 2003). According to Pathak et al. (2003) negative trends in solar radiation and an increase in minimum temperature, resulting in declining trends of potential yields of rice and wheat in the Indo-Gangetic plains of India.

In March 2004, temperatures were higher in the IndoGangetic plains by 3 to $6^{\circ} \mathrm{C}$, as a result, wheat crop matured earlier by 10-20 days and wheat production dropped by more than $4 \mathrm{~m} \mathrm{t}$ in the country and other crops, such as mustard, peas, tomatoes, onion, garlic and other vegetable and fruit crops were also affected significantly (Samra and Singh, 2004). Area coverage of the rainy-season crops reduced more than $15 \mathrm{~m}$ ha due to the drought of 2002 and resulted in a loss of more than $10 \%$ in food production (Samra and Singh, 2002). Agriculture is adversely affected not only by an increase or decrease in the overall amounts of rainfall, but also by shifts in the timing of the rainfall.

\section{Yield responses to future climate projections}

IPCC and other global studies projected that unless we adapt, there is a probability of 10 to $40 \%$ loss in crop production in India by 2080 to 2100 due to global warming despite beneficial aspects of increased $\mathrm{CO}_{2}$ (Parry et al., 2004; IPCC, 2007). North Indian states and Bangladesh are highly susceptible due to erratic changes in rainfall and temperature (World Bank, 2008). In India, an increase in temperature by $1.50^{\circ} \mathrm{C}$ and decrease in the precipitation of $2 \mathrm{~mm}$, reduces the rice yield by 3 to $15 \%$ (Ahluwalia and Malhotra, 2006). Wheat yields are predicted to fall by 5 to $10 \%$ with every increase of $1^{\circ} \mathrm{C}$ and overall crop yields could decrease up to $30 \%$ in south Asia by the mid- $21^{\text {st }}$ century (IPCC, 2001).

Hundal and Kaur (1996) examined the climate change impact on various crop in Punjab using CERES models and 
Table 1: Climate change projection for different seasons in India.

\begin{tabular}{lccccc}
\hline \multirow{2}{*}{ Year } & \multirow{2}{*}{ Season } & \multicolumn{2}{c}{ Temperature change $\left({ }^{\circ} \mathrm{C}\right)$} & \multicolumn{2}{c}{ Rainfall change $(\%)$} \\
\cline { 3 - 6 } & & Lowest & Highest & Lowest & Highest \\
\hline 2050s & Annual & 2.23 & 2.87 & 5.36 & -9.22 \\
& Rabi & 2.54 & 3.18 & 7.18 & 3.34 \\
& Kharif & 1.81 & 2.37 & 7.48 & 10.52 \\
& Annual & 3.53 & 5.55 & -24.83 & 9.90 \\
& Rabi & 4.14 & 6.31 & 10.10 & -4.50 \\
& Kharif & 2.91 & 4.62 & 15.18 \\
\hline
\end{tabular}

Source: Lal et al. (2001)

Table 2: Projected changes in climate in India 2070-2099.

\begin{tabular}{|c|c|c|c|c|}
\hline Region & Jan-March & April-June & July-Sep. & Oct.-Dec. \\
\hline \multicolumn{5}{|c|}{ Temperature change $\left({ }^{\circ} \mathrm{C}\right)$} \\
\hline Northeast & 4.95 & 4.11 & 2.88 & 4.05 \\
\hline Northwest & 4.53 & 4.25 & 2.96 & 4.16 \\
\hline Southeast & 4.16 & 3.21 & 2.53 & 3.29 \\
\hline Southwest & 3.74 & 3.07 & 2.52 & 3.04 \\
\hline \multicolumn{5}{|c|}{ Precipitation change (\%) } \\
\hline Northeast & -9.30 & 20.30 & 21.00 & 7.50 \\
\hline Northwest & 7.20 & 7.12 & 7.20 & 57.00 \\
\hline Southeast & -32.90 & 29.70 & 10.90 & 0.70 \\
\hline Southwest & 22.30 & 32.30 & 8.80 & 8.50 \\
\hline
\end{tabular}

Source: Cline (2007).

Table 3: Yield reduction of different crops during the period 20712100.

\begin{tabular}{lcc}
\hline Crop & Region & $\begin{array}{c}\text { Yield reduction } \\
(\%)\end{array}$ \\
\hline Rice (Irrigated) & Haryana & 32.00 \\
Rice (Rainfed) & Punjab & 18.00 \\
& Orissa & 28.00 \\
Wheat & Madhya Pradesh & 18.00 \\
& East Rajasthan & 21.00 \\
& West Rajasthan & 18.00 \\
Rapeseed-Mustard & East Madhya Pradesh. & 14.00 \\
Potato & - & 39.00 \\
\hline
\end{tabular}

simulation predicted that if all other climate variables remain constant, temperature increase of 1,2 and $3^{\circ} \mathrm{C}$ from present day condition, would reduce the grain yield of wheat by 8.10 , 18.70 and $25.70 \%$, rice by $5.40,7.40$ and $25.10 \%$, maize by $10.40,14.60$ and $21.40 \%$ and seed yield in groundnut by $8.70,23.20$ and $36.20 \%$, respectively. Agriculture will be worst affected in the coastal regions of Gujarat and Maharashtra, where agriculturally fertile areas are vulnerable to inundation and salinization. Changes in the soil, pests and weeds brought by climate change will also affect agriculture in India (TERI, 2002). Shortfalls in rainfall can reduce irrigation water supplies, leading to reduce areas under irrigated crops and potentially increased areas under rain-fed crops (Kumar et al., 2004).
Decrease in duration of cropping season and their yields, as temperatures increase in different parts of India between 2010 and the 2070s was predicted. However, the magnitude of this response will vary with crop, season, region and climate change scenarios. There are two types of scenarios in simulation (i) Pessimistic scenario: highest increase in temperature and lowest increase in $\mathrm{CO}_{2}$. detrimental to crop growth and (ii) Optimistic scenario: large increase in $\mathrm{CO}_{2}$ and a small change in temperature, promoting crop growth. In both scenarios irrigated rice yields predicted to have a small gain in production, anywhere in the country. However, wheat yields in central India are likely to suffer by up to $2 \%$ and likely to improve by $6 \%$ in the under the pessimistic scenario and optimistic scenario respectively. Sorghum, being a $\mathrm{C}_{4}$ plant, does not show any significant response to increase in $\mathrm{CO}_{2}$ and hence different scenarios do not affect its yield. Meta-analysis of $\mathrm{CO}_{2}$ enrichment experiments in fields has shown that in field environment, $550 \mathrm{ppm} \mathrm{CO}$ leads to a benefit of 8 to $10 \%$ in yield in wheat and rice, up to $15 \%$ in soybean and almost negligible in maize and sorghum (Long et al., 2005). According to PRECIS regional climate model, during the period 2071 to 2100 , yield reduction of different crop in different regions has been given in the Table 3 (Chaudhari, et al., 2009).

According to some studies, there will be a clear negative response of yields to increased minimum temperatures for rabi crops: wheat, potato and rapeseed-mustard while mixed response for kharif rice. In general, the reduction in crop 
yields up to 5.00 to $13.40 \%$ was observed with unit increase in minimum temperature. The crop yield also showed negative response to increased maximum temperature. It is estimated that every $1^{\circ} \mathrm{C}$ increase in temperature is likely to lead to a 5 to $10 \%$ reduction in yields of some crops (Chaudhari et al.2009; Pachauri 2009).

\section{Rice and Wheat}

With every $1^{\circ} \mathrm{C}$ increase in mean temperatures above $17^{\circ} \mathrm{C}$ during the terminal spikelet initiation to anthesis, there was a decline of 600 to 650 grains $\mathrm{m}^{-2}$ in wheat crop (Saini and Nanda, 1986). Sinha and Swaminathan (1991) estimated that a $2^{\circ} \mathrm{C}$ increase in mean air temperature could decrease rice yield by about 0.75 tha in the high yield areas and by about $0.06 \mathrm{t} / \mathrm{ha}$ in the low yielding coastal regions. Further, $0.50^{\circ} \mathrm{C}$ increase in winter temperature would reduce wheat crop duration by seven days and $10 \%$ reduction in wheat production in the high yielding states of Northern India. Aggarwal and Sinha (1993) reported that at $425 \mathrm{ppm} \mathrm{CO}$ concentration and no rise in temperature, wheat grain yield at all levels of production (i.e. potential, irrigated and rainfed) increased significantly. In northern India, a $1^{\circ} \mathrm{C}$ rise in mean temperature had no significant effect on potential yields but irrigated and rainfed yields increased in most places. An increase of $2^{\circ} \mathrm{C}$ in temperature reduced potential wheat yields at most places. Projections indicate the possibility of loss of 4 to $5 \mathrm{~m}$ tonnes in wheat production with every rise of $1^{\circ} \mathrm{C}$ temperature throughout the growing period with current land use (Aggarwal, 2008). Aggarwal and Kalra (1994) estimated the effect of climate change on productivity of wheat in India. At $425 \mathrm{ppm} \mathrm{CO}{ }_{2}$ concentration and no rise in temperature, grain yield at all levels of production increased significantly at all places. No significant effect on potential yields was observed with $1^{\circ} \mathrm{C}$ rise in mean temperature. An increase of $2^{\circ} \mathrm{C}$ in temperature reduced potential yields at most places. Lal et al. (1998) found that under elevated $\mathrm{CO}_{2}$ levels, yields of rice and wheat increased positively ( 15 and $28 \%$ with doubling of $\mathrm{CO}_{2}$ ). However, $3^{\circ} \mathrm{C}$ and $2^{\circ} \mathrm{C}$ rise in temperature cancelled out the positive effect of increased $\mathrm{CO}_{2}$ on wheat and rice respectively. The combined effect of enhanced $\mathrm{CO}_{2}$ and imposed thermal stress on the wheat and rice crops was $21 \%$ and $4 \%$ increase in yield.

CERES-rice model to $\mathrm{CO}_{2}$ concentration changes (Saseendran et al., 2000) indicated that over the Kerala State, an increase in $\mathrm{CO}_{2}$ concentration leads to yield increase and enhanced the water use efficiency. For a positive change in temperature up to $5^{\circ} \mathrm{C}$, there is a continuous decline in the rice yield. For every $1^{\circ} \mathrm{C}$ increment, the decline in yield is about $6 \%$. Also, in another experiment it was noticed that the physiological effect of ambient $\mathrm{CO}_{2}$ at $425 \mathrm{ppm}$ concentration compensated for the rice yield losses up to $2^{\circ} \mathrm{C}$ increased in temperature. Aggarwal and Mall (2002) reported that in current level of management increase of 1 to $2^{\circ} \mathrm{C}$ temperature without any increase in $\mathrm{CO}_{2}$ resulted in 3 to $17 \%$ decrease in grain yield in different regions. As the temperature increased, rice yields were less affected in eastern and western India, moderately affected in north whereas severely affected in southern India. A doubling of $\mathrm{CO}_{2}$ resulted in 12 to $21 \%$ increases in yield in different regions. The beneficial effect of $450 \mathrm{ppm} \mathrm{CO}$ was nullified by an increase of $1.9-2.0^{\circ} \mathrm{C}$ in northern and eastern regions and by 0.90 to $1.00^{\circ} \mathrm{C}$ in southern and western regions. In improved level of management increase of 1 to $4^{\circ} \mathrm{C}$ temperature without any increase in $\mathrm{CO}_{2}$ resulted in a 5 to $30 \%$ decrease in grain yields in different regions. Increase of 28 to $35 \%$ in yields of rice was obtained as atmospheric $\mathrm{CO}_{2}$ doubled. The beneficial effect of $450 \mathrm{ppm} \mathrm{CO}$ was nullified by an increase of 1.20 to $1.70^{\circ} \mathrm{C}$ in northern and eastern regions and by 0.90 to $1.00^{\circ} \mathrm{C}$ in southern and western regions. Kumar and Parikh (2001), found that the overall impacts due to the climate change scenario $\left(2^{\circ} \mathrm{C}\right.$ rise in temperature and $7 \%$ increase in precipitation) are negative. The northern states which grow predominantly wheat in the winter season, experience most negative effects, along with the coastal districts of Tamil Nadu. On the other hand, the eastern district of West Bengal and parts of Bihar, seem to benefit from the changes in future.

According to projected impacts of climate change on crops in the western ghats in the 2030 scenario by Kumar et al. (2011) for rainfed rice, irrigated rice in parts of southwestern Karnataka and the northern-most districts of Kerala is likely to gain due to $\mathrm{CO}_{2}$ fertilization in some locations. In most of the Western Ghats region, the monsoon rainfall is likely to increase up to $15 \%$. In areas with high rainfall like Western Ghats, increased rainfall can reduce sunshine duration, causing limitation to photosynthetic rates which will reduce yields during the kharif season.

\section{Millets}

Climate change is likely to reduce yields of maize and sorghum up to $50 \%$ depending upon the region. These crops have $\mathrm{C}_{4}$ photosynthetic system and have relatively lesser advantage than $\mathrm{C}_{3}$ crops at higher $\mathrm{CO}_{2}$ concentrations (Ainsworth and Long, 2005). Rao et al. (1995) using CERESsorghum simulation model predicted that decrease in yield and biomass of rainy season sorghum at Hyderabad and Akola under all climate change scenarios. The positive effects of increased $\mathrm{CO}_{2}$, if any, were masked by the adverse effects of predicted increase in temperature resulting in shortened crop growing seasons. Chatterjee (1998) used CERES-sorghum model and observed increase in temperature consistently decreased the sorghum yields from the present day conditions. Increase in temperature by 1 and $2^{\circ} \mathrm{C}$ sorghum decreased the grain yields by 7 to $12 \%$, on an average. A further increase in temperature drastically reduced the potential yields by 18 to $24 \%$, on an average. Increase in $50 \mathrm{ppm} \mathrm{CO}$ increase yields by only $0.50 \%$ and this nullified with $0.08^{\circ} \mathrm{C}$ temperature increase. The beneficial effect of $700 \mathrm{ppm} \mathrm{CO}$ was nullified by an increase of only $0.90^{\circ} \mathrm{C}$ in temperature. 
Sahoo (1999) used CERES-maize crop model and predicted that rise in temperature decreased the maize yield in both for irrigated and rainfed conditions. At $\mathrm{CO}_{2}$ level of $350 \mathrm{ppm}$, grain yield decreased continuously with temperature rise till $4^{\circ} \mathrm{C}$, where the yield decreased by about $30 \%$ over the present day condition. At $\mathrm{CO}_{2}$ level of 700 ppm, grain yield increased by about $9 \%$ over the present day condition. The temperature rise decreased the yield which was around $8 \%$ per degree rise. For IPCC scenarios, increase of $1.80^{\circ} \mathrm{C}$ temperature for India and $425 \mathrm{ppm} \mathrm{CO}$ by the year 2030 , potential maize yields would be severely affected (about 18\%). Maize and sorghum yield in monsoon are projected to be adversely affected due to rise in temperature; but increased rainfall can partly offset those loses (Byjesh et al., 2010). However, complete amelioration of yield loss beyond $2^{\circ} \mathrm{C}$ rise may not be attained even after doubling of rainfall in sorghum (Srivastava et al., 2010). In Rajasthan, a $2^{\circ} \mathrm{C}$ rise in temperature was estimated to reduce production of pearl millet by 10 to $15 \%$. (Ramakrishna et al., 2002). Increase in rainfall in already high rainfall zones is detrimental to production of maize and sorghum as any coincidence of high rainfall with the pollination period will affect the production.

\section{Pulses and oilseed}

The production of brassica crop is likely to increase and is likely to be shifted in some more relatively drier region's than where it is grown presently (Uprety et al., 1996). Mandal (1998) used CROPGRO-chickpea model and observed increase in temperature up to $2^{\circ} \mathrm{C}$ did not influence potential yield of chickpea as well as aboveground biomass significantly. Irrigated yield, which averaged around $58 \%$ of the potential yield, increased with temperature rise up to $2^{\circ} \mathrm{C}$. Total crop duration got reduced only by 4 days with $2^{\circ} \mathrm{C}$ rise. Crop yield under rain-fed condition was much lower, but the effect of temperature rise on crop growth and yield were similar as in case of irrigated condition. There was a linear increase in grain yield as the $\mathrm{CO}_{2}$ concentration increased from 350 to $700 \mathrm{ppm}$ under potential, irrigated and rainfed conditions. Potential grain yield of pigeon pea decreased greatly over the control when the temperature was increased even by $1^{\circ} \mathrm{C}$.

Lal et al. (1999) projected $50 \%$ increased yield for soybean for a doubling of $\mathrm{CO}_{2}$ in Central India by using CROPGRO-soybean model. However, $3^{\circ} \mathrm{C}$ rise in temperature almost cancelled out these positive effects by reducing the total duration of the crop by inducing early flowering and shortening the grain fill period. A decline in daily rainfall amount by $10 \%$ restricts the grain yield to about $32 \%$. Acute water stress due to prolonged dry spells during monsoon season could be a critical factor for the soybean productivity even under the positive effects of elevated $\mathrm{CO}_{2}$ in the future. Mall et al. (2004) with similar model and GCM projected climate change scenarios predicted mean decline in yields across different scenarios ranged from $14 \%$ in Pune (west India) to $23 \%$ in Gwalior (central India). Decline in soybean yield is found to be less in west and south India as compared to other parts of the country.

Most of the simulation studies have shown a decrease in duration and yield of crops as temperature increased in different parts of India. Within agriculture, rainfed agriculture will be most impacted by climate change. Though most rainfed crops tolerate high temperatures but the crops grown during rabi are vulnerable to changes in minimum temperatures (Venkateswarlu and Rao, 2010). These studies have also indicated that the direct impacts of climate changes would be small on kharifcrops but kharif agriculture will become vulnerable due to increased incidence of weather extremes. Rabi crop production may become comparatively more vulnerable due to larger increase in temperature, asymmetry of day and night temperature and higher uncertainties in rainfall. The impacts of the climate change on Indian agriculture would be small in near future, but in long run it may be seriously affected depending upon season, level of management and magnitude of climate change.

\section{Mitigation ad adaptation strategies}

'Adaptation' is nothing but the adjustments in human or natural ecosystem in response to climate change and it moderately harm or destruct the opportunities (IPCC, 2007). While 'Mitigation' is any technical modification that reduces the addition of GHGs into atmosphere per unit of output (IPCC, 2007). The important mitigation and adaptation strategies include adjustment in sowing dates, breeding of plants that are more resilient to variability of climate and improvement in agronomic practices. Attri and Rathore (2003) suggested the adaptation strategies for wheat by enhancement of sowing by 10 days in late-sown cultivars which resulted in higher yields under a modified climate. Similar results observed by Mall et al. (2004) for increased soybean yields at all the locations in India by reducing the negative impacts of temperature increases. Changing of sowing dates is a no-cost decision that can be taken at the farmer level. Changes in the cropping sequence, irrigation and agriculture land use can be additional alternative options for adaptation in agriculture. There is need to be identify district or agro climatic regions vulnerable to climate change and identify suitable adaptation practices to be followed in order to sustain the productivity of these regions to some extent.

\section{Government of india initiatives for climate change adaptation}

Govt. of India took several initiatives aiming to combat global warming and for climate change adaptation. These missions implemented package of several technologies developed by the ICAR. Some important initiatives are elaborated with key objectives in the no. Table 4 (Handbook, 2018).

\section{Impacts of national programmes and policies}

Impact assessment of any scheme or policy is very important to assess the benefits of the work or plan toward the society. 
Table 4: Policies of Government of India with their main objectives.

\begin{tabular}{|c|c|c|}
\hline Name of policy & Year of start & Main objectives \\
\hline Agro-Advisory Services & 1988 & Providing real time location and crop specific agro-met services \\
\hline National Action Programme to Combat Desertification & 2001 & Prevention of land degradation and reclamation of decertified land \\
\hline $\begin{array}{l}\text { National Action Plan on Climate Change (NAPCC) and } \\
\text { State Action Plan on Climate Change (SAPCC) }\end{array}$ & 2008 & $\begin{array}{l}\text { To create awareness on the risks posed by global climate } \\
\text { changes and steps to encounter the same. }\end{array}$ \\
\hline National Water Mission (NWM) & 2009 & $\begin{array}{l}\text { To conserving the water sources and minimizing its wastage } \\
\text { and also to optimize water use efficiency by } 20 \% \text { including } \\
\text { agriculture sector. }\end{array}$ \\
\hline $\begin{array}{l}\text { Agricultural Contingency Plans and National Innovations } \\
\text { on Climate Resilient Agriculture (NICRA) }\end{array}$ & 2011 & $\begin{array}{l}\text { To enhancing resilience of Indian agriculture to adverse climate } \\
\text { changes by adopting innovative technologies. }\end{array}$ \\
\hline Green India Mission (GIM) & 2014 & $\begin{array}{l}\text { To protect, restore and enhance the diminishing forest cover } \\
\text { in India. }\end{array}$ \\
\hline National Mission on Sustainable Agriculture (NMSA) & $2014-15$ & $\begin{array}{l}\text { To promote resource conservation, enhancing or restoring the } \\
\text { soil fertility, specifically in dry lands or rainfed agriculture areas }\end{array}$ \\
\hline National Adaptation Fund for Climate Change (NAFCC) & $2015-16$ & $\begin{array}{l}\text { For supporting adaptation activities dealing with mitigating the } \\
\text { adverse effects of global climate change. }\end{array}$ \\
\hline Pradhan Mantri Krishi Sinchayee Yojna (PMSKY) & 2015 & $\begin{array}{l}\text { The main motto of this scheme is 'Har Khet Ko Paani' to } \\
\text { improve water use efficiency, 'More crop per drop' }\end{array}$ \\
\hline Pradhan Mantri Fasal Bima Yojna (PMFBY) & 2016 & $\begin{array}{l}\text { To reduce the agricultural distress during monsoon fluctuations } \\
\text { or any other natural calamity. }\end{array}$ \\
\hline Sub-mission on Agro-forestry & 2016-17 & Planting trees on farm bunds to bring sustainability in agriculture \\
\hline
\end{tabular}

Table 5: Impact of important policies of India.

\begin{tabular}{|c|c|}
\hline Impacts of Policies & Impact \\
\hline Irrigation policies & 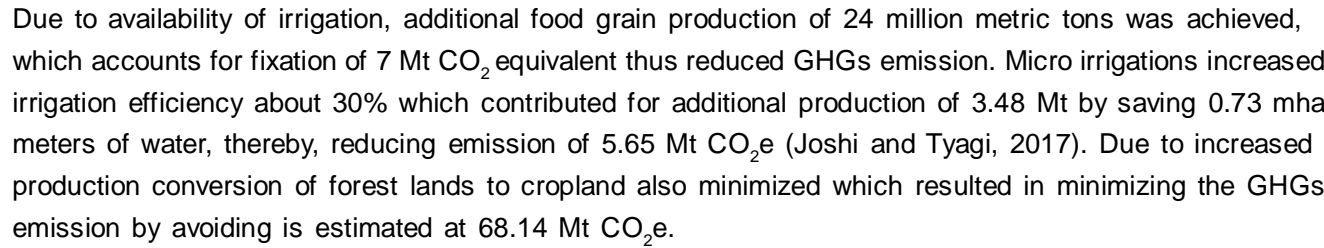 \\
\hline Fertilizer policies & $\begin{array}{l}\text { Use of optimum fertilizers increases food grain production by } 13.66 \mathrm{Mt} \text { which avoided the conversion of } \\
11.48 \mathrm{mha} \text { of forestland to cropland, thereby, reducing } 2013 \mathrm{Mt} \text { of GHGs emissions (Joshi and Tyagi, 2017). }\end{array}$ \\
\hline Agro-forestry policy & $\begin{array}{l}\text { Awareness created under this policy for agro-forestry and now area under agro-forestry is increasing. } \\
\text { Carbon fixation due to agro forestry will lead to reduced GHGs. }\end{array}$ \\
\hline $\begin{array}{l}\text { Contingency plans and } \\
\text { Resilient model villages }\end{array}$ & $\begin{array}{l}\text { Large-scale awareness created and capacity building of farmers was done in resilient agriculture. Sowing } \\
\text { area reduction during drought years }(2014,2015,2016) \text { was off-set to the extent of } 6-9 \% .151 \text { climate } \\
\text { resilient villages established by ICAR. Computation of village carbon balance of climate resilient villages } \\
\text { showed reduction of GHG emissions (Srinivasarao et al., 2016b). }\end{array}$ \\
\hline
\end{tabular}

Impact of some important policies of India toward the adoption and mitigation of climate change in India is given in the Table 5.

\section{CONCLUSION}

Climate change is the greatest challenge for sustainable development especially in agriculture. Indian agriculture faces the challenge of feeding a billion people in a changing climatic scenario because it is the main source of livelihood for almost $60 \%$ of the country's total population. Changes in rainfall patterns of India reported in many studies. In India more than $60 \%$ of agriculture is totally depend on rainfall. So change in rainfall amount or its distribution can affect Indian agriculture seriously. Change in temperature as reported for present and for future projection will also going to decrease the productivity of many crops. There is need to identify district or agro-climatic regions vulnerable to climate change and identify suitable adaptation and mitigation practices to be followed in order to sustain the productivity of these regions. The effort toward reducing the GHGs emissions and adoption strategies for the changing climat would definitely help to fight the Indian agriculture 
sector with harmful impacts of climate change and to stand with sustainable growth and production.

\section{REFERENCES}

Aggarwal, P.K. (2003). Impact of climate change on Indian agriculture. Journal of Plant Biology. 30(2): 189-198.

Aggarwal, P.K. (2008). Global climate change and Indian agriculture: impacts, adaptation and mitigation. Indian Journal of Agricultural Sciences. 78(11): 911-919.

Aggarwal, P.K. and Kalra, N. (1994). Simulating the effect of climatic factors, genotype and management on productivity of wheat in India. Indian Agricultural Research Institute Publication, New Delhi, India. pp. 156.

Aggarwal, P.K. and Mall, R.K. (2002). Climate change and rice yields in diverse agro-environments of India. II. Effect of uncertainties in scenarios and crop models on impact assessment. Climatic Change. 52(3): 331-343.

Aggarwal, P.K. and Sinha, S.K. (1993). Effect of probable increase in carbon dioxide and temperature on productivity of wheat in India. Journal of Agricultural Meteorology. 48(5): 811-814.

Ahluwalia, V.K. and Malhotra, S. (2006). Environmental Science. Anne Books India, New Delhi.

Ainsworth, E.A. and Long, S.P. (2005). What have we learned from 15 years of free-air $\mathrm{CO}_{2}$ enrichment (FACE)? A metaanalytic review of the response of photosynthesis, canopy properties and plant production to rising $\mathrm{CO}_{2}$. New Phytology. 165: 351-372.

Anonymous (2019). Global Climate Change: Implications for Indian Agriculture. https://icar.org.in/node/1738

Attri, S.D. and Rathore, L.S. (2003). Simulation of impact of projected climate change on wheat in India. International Journal of Climatology. 23: 693-705.

Attri, S.D. and Tyagi, A. (2010). Climate Profile of India: Contribution to the Indian Network of Climate Change Assessment (National Communication-II); Ministry of Environment and Forests, Published By Environment Monitoring and Research Centre, India Meteorological Department.

Bal, S.K. and Minhas, P.S. (2017). Atmospheric Stressors: Challenges and Coping Strategies, In: Abiotic Stress Management for Resilient Agriculture. Springers Nature Singapore Pte. Ltd. pp. 9-50.

Byjesh, K., Kumar, N.S. and Aggarwal, P.K. (2010). Simulating impacts, potential adaptation and vulnerability of maize to climate change in India, Mitigation and Adaptation Strategies for Global Change. Springer. 15(5): 413-431.

Chatterjee, A. (1998). Simulating the impact of increase in temperature and $\mathrm{CO}_{2}$ on growth and yield of maize and sorghum. M.Sc. Thesis, Indian Agricultural Research Institute, New Delhi.

Chaudhari, K.N., Oza, M.P. and Ray, S.S. (2009). Impact of climate change on yields of major food crops in India. ISPRS Archives XXXVIII-8/W3 Workshop Proceedings: Impact of Climate Change on Agriculture.

Cline, W. (2007). Global Warming and Agriculture: Impact Estimates by Country. Peterson Institute, Washington, D.C.

Handbook. (2018). Schemes, Programmes and Missions Promoting Agricultural Development and Farmer's Welfare. Ministry of Agriculture and Farmers Welfare.
Hundal, S.S. and Kaur, P. (1996). Climate Change and Its Impact on Crop Productivity in The Punjab, India. In: Climate Variability and Agriculture. New Delhi, India, pp. 410.

IMD (2009). India Meteorological Department: Annual Climate Summary. Published by National Climate Centre, Pune.

IMD (2020). India Meteorological Department: Annual Climate Summary. Published by National Climate Centre, Pune.

IPCC (2001). Climate Change 2001- The Scientific Basis. Contribution of Working Group I to the Third Assessment Report of the Inter governmental Panel on Climate Change, Cambridge University Press, Cambridge, UK. pp. 881.

IPCC (2007). Impacts, Adaptation and Vulnerability: Summary for Policy Makers. Inter governmental Panel on Climate Change, Cambridge University Press. UK.

Joshi, P.K. and Tyagi, N.K. (2017). Assessment of Government Policies and Programmes on Climate Change- Adaptation, Mitigation and Resilience in South Asian Agriculture. In: Agriculture under Climate Change Threats, Strategies and Policies, Section-VI. pp. 431-434.

Kothawale, D.R., Munot, A.A. and Kumar K.K. (2010). Surface air temperature variability over India during 1901-2007 and its association with ENSO. Climate Research. 42: 89-104.

Kumar, K.K., Kumar, K.R., Ashrit, R.G., Deshpande, N.R. and Hansen, J.W. (2004). Climate impacts on Indian agriculture. International Journal of Climatology. 24(11): 1375-1393.

Kumar, K.S. and Parikh, J. (2001). Indian Agriculture and Climate sensitivity. Global Environment Change. 11: 147-154.

Kumar, S.N., Aggarwal, P.K., Rani, S., Jain, S., Saxena, R. and Chauhan, N. (2011). Impact of climate change on crop productivity in Western Ghats, coastal and north-eastern regions of India. Current Science. 101(3): 10.

Lal, M., Nozawa, T., Emori, S., Harasawa, H., Takahashi, K., Kimoto, M., Abe-Ouchi, A., Nakajima, T., Takemura T. and Numaguti, A. (2001). Future climate change: Implications for Indian summer monsoon and its variability. Current Science. 81(9): 1205

Lal, M., Singh, K.K., Srinivasan, G., Rathore, L.S. and Saseendran, A.S. (1998). Vulnerability of rice and wheat yields in NWIndia to future change in climate. Agricultural and Forest Meteorology. 89: 101-114.

Lal, M., Singh, K.K., Srinivasan, G., Rathore, L.S., Naidu, D. and Tripathi, C.N. (1999). Growth and yield responses of soybean in Madhya Pradesh, India to climate variability and change. Agricultural and Forest Meteorology. 93: 6566.

Long, S.P., Ainsworth, E.A., Leakey, A.D.B. and Morgan, P.B. (2005). Global food insecurity. Treatment of major food crops with elevated carbon dioxide or ozone under largescale fully open-air conditions suggests recent models may have overestimated future yields. Philosophical Transactions of the Royal Society B. Biological Sciences. 360: 2011-20.

Mall, R.K., Lal M., Bhatia, V.S., Rathore, L.S. and Singh, R. (2004). Mitigating climate change impact on Soybean productivity in India: A simulation study. Agricultural and Forest Meteorology. 121 (1-2): 113-125. 
Mandal, N. (1998). Simulating the impact of climatic variability and climate change on growth and yield of chickpea and pigenonpea crops. M.Sc. Thesis, Indian Agricultural Research Institute, New Delhi.

NATCOM (2004). India's Initial National Communication to the UNFCCC Report. Ministry of Environment and Forests, Government of India. New Delhi.

Pachauri, R.K. (2009). Climate change and its implications for India's fragile ecosystems. In: The Human Impact of Climate Change: Policy Notes for Parliamentarians. CLRA: New Delhi.

Pal, I. (2009). Rainfall Trends in India and Their Impact on Soil Erosion and Land Management. Doctoral Thesis, Department of Engineering, University of Cambridge. UK.

Parry, M.L., Rosenzweig, C., Iglesias, Livermore, A.M. and Fischer, G. (2004). Effects of climate change on global food production under SRES emissions and socio-economic scenarios. Global Environment Change. 14: 53-67.

Pathak, H., Ladha, J.K., Aggarwal, P.K., Peng, S., Das, S., Singh, Y., Singh, B., Kamra, S.K., Mishra, B., Sastri, A.S.R.A.S., Aggarwal, H.P., Das, D.K. and Gupta, R.K. (2003). Trends of climatic potential and on-farm yields of rice and wheat in the Indo-Gangetic Plains. Field Crops Research. 80: 223-234.

Ramakrishna, Y.S., Kesava Rao, A.V.R., Nageswara Rao, G. and Aggarwal, P.K. (2002). Impacts of climate change scenarios on Indian agriculture: Evidences. South Asia Expert Workshop on Adaptation to Climate Change for Agricultural Productivity. 1-3 May 2002. New Delhi.

Rao, G.D., Katyal, J.C., Sinha, S.K. and Srinivas, K. (1995). Impacts of climate change on sorghum productivity in India: Simulation study. In: Climate Change and Agriculture: Analysis of Potential International Impacts. American Society of Agronomy, USA, Special Publication. 59: 325337.

Ravindranath, N.H. (2007). Forests in India-Take Action Now. In: The Hindu Survey of the Environment. The Hindu, Special Issue. New Delhi.

Sahoo, S.K. (1999). Simulating growth and yield of maize in different agro-climatic regions. M.Sc. Thesis, Indian Agricultural Research Institute. New Delhi.

Saini, A.D. and Nanda, R. (1986). Relationship between incident radiation, leaf area and dry matter yield in wheat. Indian Journal of Agricultural Sciences. 56: 512-519.

Samra, J.S. and Singh, G. (2002). Drought Management Strategies. Indian Council of Agricultural Research. New Delhi. pp. 68.
Samra, J.S. and Singh, G. (2004). Heat Wave of March: Impact on Agriculture. Indian Council of Agricultural Research, New Delhi. pp. 32.

Saseendran, A.S., Singh, K.K., Rathore, L.S., Singh, S.V. and Sinha, S.K. (2000). Effects of climate change on rice production in the tropical humid climate of Kerala, India. Climatic Change. 44: 495-514.

Singh, N. and Sontakke, N.A. (2002). On climatic fluctuations and environmental changes of the Indo-Gangetic plains, India. Climatic Change. 52: 287-313.

Sinha, S.K. and Swaminathan, M.S. (1991). Deforestation, Climate Change and Sustainable Nutrition Security: A Case Study of India. Climate Change. 19: 201-209.

Srinivasarao, Ch., Gopinath, K.A., Prasad, J.V.N.S., Prasanna, K. and Singh, A.K. (2016a). Climate resilient villages for sustainable food security in tropical India: Concept, process, technologies, institutions and impacts. Advances in Agronomy. 140(3): 101-214.

Srinivasarao, Ch., Sudharani, Y., Girija, V., Sharma, K.L., Maruti Sankar, G.R., Prasad, J.V.N.S., Prasad, Y.G. and Saharawat, K.L. (2016b). Assessing village level carbon balance due to greenhouse gas mitigation intervention using EX-ACT model. International Journal of Environmental Science and Technology. 13(1): 97-112.

Srivastava, A., Kumar Naresh, S. and Aggarwal, P.K. (2010). Assessment on vulnerability of sorghum to climate change in India, Agriculture. Ecosystems and Environment. 138: 160-169.

Stephenson, B.D., Douville, Herve and Rupakumar, K. (2001). Searching for a fingerprint of global warming in the Asian summer monsoon. Mausam. 52(1): 213-220.

TERI (2002). India Specific Impacts of Climate Change. Tata Energy Research Institute. http://www.terin.org/climate/impacts. htm.

Uprety, D.C., Chakravarty, N.V.K., Katiyal, R.K. and Abroal, Y.P. (1996). Climate Variability and Brassica. In: Climate Variability and Agriculture. Narosa Publishing House, New Delhi, India. pp. 264-280.

Venkateswarlu, B. and Rao, R.C.A. (2010). Rainfed Agriculture: Challenges of Climate Change. Agriculture Today Yearbook. pp. $43-45$.

World Bank (2008). World Bank's Approach to Climate Change in South Asia: An Overview. World Bank Information Centre. http://www.bicusa.org. 